\title{
OVER-DISTENSION THERAPY OF THE BLADDER IN PARAPLEGIC PATIENTS USING SELF-CATHETERISATION: A PRELIMINARY STUDY
}

\author{
By E. Iwatsubo, M.D., S. Komine, M.D., H. Yamashita, and \\ A. Imamura, M.D. and T. Akatsu, M.D. \\ Division of Urology, Iizuka Spinal Injuries Centre, Iizuka, Fapan.
}

Summary. Over-distension therapy was performed in 60 patients during the period of spinal shock after complete spinal cord injury.

Forty-five developed upper motor neurone (UMN) hypo-active decompensated bladder function and 39 achieved satisfactory social activity without urinary incontinence using self-catheterisation. Self catheterisation appeared a safer and more comfortable means of urinary management than trigger voiding in paraplegics with complete spinal cord injury. This is a preliminary communication as it is hoped that a comparative study will follow in due course.

Key words: Over-distension of the bladder; Complete paraplegia; Selfcatheterisation.

\section{Introduction}

THE BLADDER of spinal cord injury patients regains its contractility after spinal shock if it is ideally managed by preventing urinary infection and overdistension. Patients with a complete lesion will regain trigger voiding but they usually suffer from reflex urinary incontinence.

It has generally been accepted that clean intermittent catheterisation (Lapides et al., I972) is a useful method in lower motor neurone (LMN) neuropathic bladder dysfunction, but it has not been generally accepted in the early stage of spinal cord injury. During the spinal shock period we allowed over-distension of the bladder (mostly in paraplegics with a complete lesion), so that they could develop a reflex decompensated bladder that would be suitable for later self-catheterisation, thus avoiding reflex urinary incontinence.

\section{Material and Methods}

We have treated 60 patients with traumatic spinal cord injury with overdistension therapy of the bladder. Forty-five males and 15 females were hospitalised within I 4 days (average 3 days), after injury. They ranged from I I to 63 years (average 33 years). The series of 60 complete spinal cord lesions included seven cervical, 39 thoracic, I 3 lumbar and one sacral lesion. The length of the follow-up ranged from 4 to 46 months (average 24 months).

Regular aseptic intermittent catheterisation evacuation of the bladder with less than $400 \mathrm{ml}$ of capacity was continued in patients with incomplete lesions and in tetraplegic males with complete lesions until they regained bladder contractility. 
Once the complete spinal cord lesion was confirmed at the end of the first week after admission, regular aseptic intermittent catheterisation was discontinued and over-distension therapy was started. In this regime the patient is allowed to take fluid $a d l i b$ and the bladder was evacuated three times a day with a urinary volume of more than $400 \mathrm{ml}$, usually over 600 to $1000 \mathrm{ml}$ on each occasion. Self-catheterisation was initiated soon after they began to sit up in bed, usually 6 weeks after injury.

The effectiveness of over-distension therapy was evaluated by urodynamic studies. The usefulness of self-catheterisation was assessed in the light of urinary incontinence, urinary infection and urinary complications.

Detrusor contraction was classified into three groups.

I. Hyper-active detrusor that recorded more than $8 \mathrm{I} \mathrm{cm} . \mathrm{H}_{2} \mathrm{O}$ pressure of contraction or more for IOI seconds duration.

2. Normo-active detrusor in which contraction showed a pressure from 48 to $8 \mathrm{I} \mathrm{cm}$. $\mathrm{H}_{2} \mathrm{O}$ lasting from 28 to $\mathrm{IOI}$ seconds. Ten healthy male adults had normoactive contraction in our urodynamic study.

3. Hypo-active detrusor in which there was weak or absent detrusor contraction.

\section{Results}

Out of 60 patients, 52 had an UMN-bladder and eight had a LMN-bladder. Fifteen patients had reflex urination without the catheter (this is called self-voiding thereafter), resulting in incontinence, while 45 patients were managed by intermittent catheterisation. In $52 \mathrm{UMN}$-bladders, 33 (63 per cent) revealed hypo-active detrusor contraction, while Io and nine patients revealed hyper-active and normo-active detrusor contraction respectively. Over-distension therapy for the UMN-bladder appears to suppress bladder contraction.

We developed a special kit for self-catheterisation (Fig. I). A silicone rubber catheter with an obturator is kept in Io per cent Bethadine-glycerine solution in the kit container. For female patients we added a small mirror which was placed on the patient's right thumb for visualisation of the urethra and secure handling of the catheter.

Self or assisted intermittent catheterisation was advised five to six times daily, every 3 to 4 hours during waking hours.

\section{The effect on urinary incontinence}

Of the 39 cases of self-catheterisation, 29 ( 74 per cent) were completely continent both day and night, the other ten preferring self-catheterisation in spite of occasional incontinence. Four out of the six cases with assisted catheterisation were female tetraplegics and were also continent. On the other hand only three out of I 5 self-voiding patients were continent (Table I). Some of those with urinary incontinence required transurethral surgery for complete voiding.

\section{The effect on urinary infection}

Urine culture was repeated weekly during aseptic intermittent catheterisation in 60 patients during hospitalisation and it was also carried out on every out-patient visit, usually at intervals of two to four weeks. The urinary 

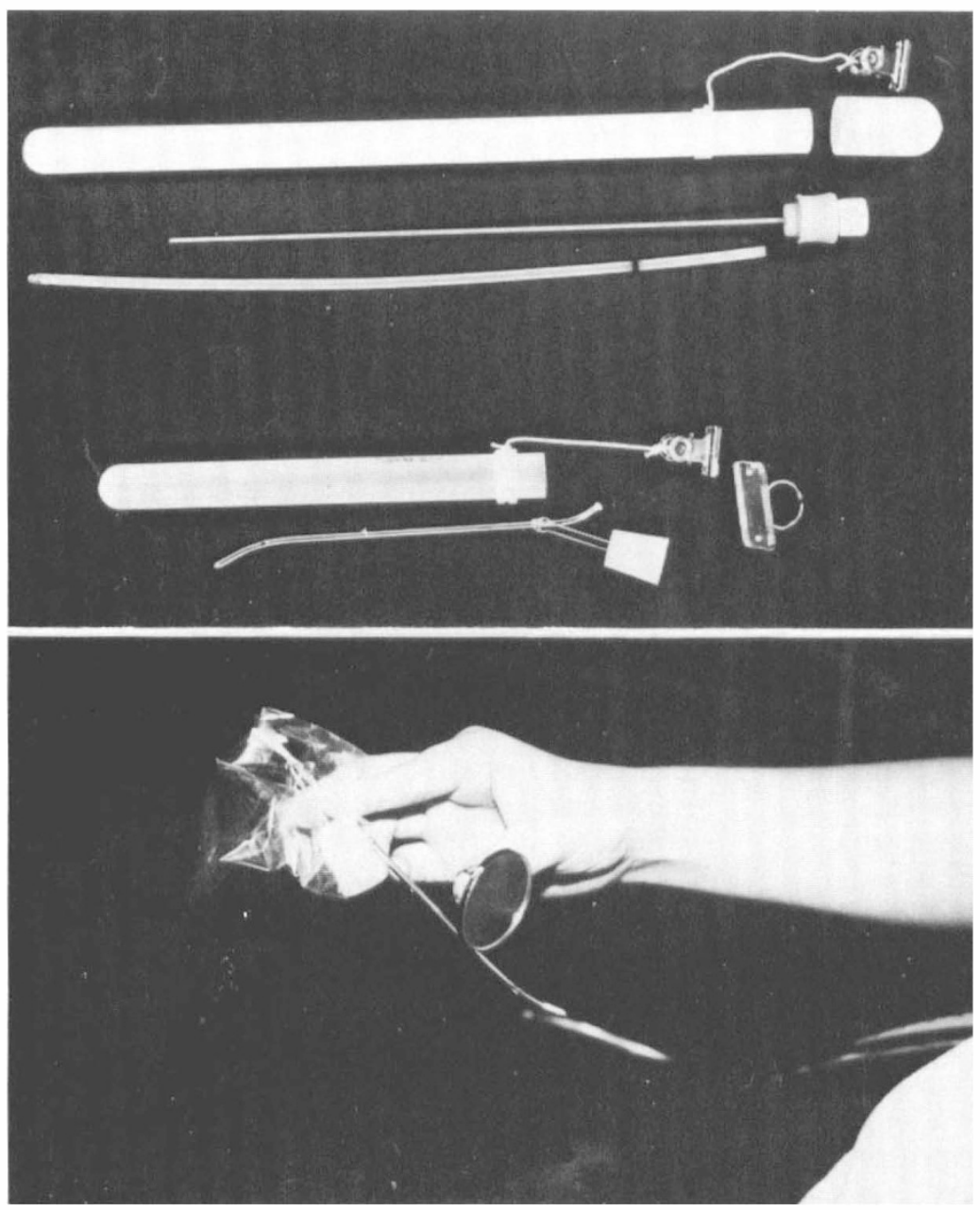

FIG. I

SIC Kit-Self-Intermittent Catheterization Kit for male and female use.

TABLE I

Clinical effectiveness for urinary incontinence and complication

\begin{tabular}{|c|c|c|c|c|c|c|}
\hline \multirow[b]{2}{*}{$\begin{array}{c}\text { Urinary } \\
\text { management }\end{array}$} & \multicolumn{3}{|c|}{ Urinary incontinence } & \multicolumn{3}{|c|}{ Urinary complication } \\
\hline & absent & occasional & frequent & absent & $\begin{array}{l}\text { bladder } \\
\text { deformity }\end{array}$ & $\begin{array}{l}\text { hydro- } \\
\text { nephrosis }\end{array}$ \\
\hline \multirow{3}{*}{$\begin{array}{l}\text { Self- } \\
\text { catheterization } \\
\text { Assisted- } \\
\text { catheterization } \\
\text { Voiding without } \\
\text { catheter }\end{array}$} & $29(74 \%)$ & 6 & 4 & $36(92 \%)$ & 2 & $\mathbf{I}$ \\
\hline & $4(67 \%)$ & 2 & o & $4(67 \%)$ & 2 & o \\
\hline & $3(20 \%)$ & 2 & IO & $9(60 \%)$ & 6 & o \\
\hline
\end{tabular}






6 weeks

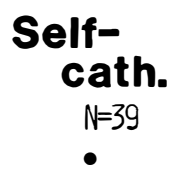

$14.7 \%$

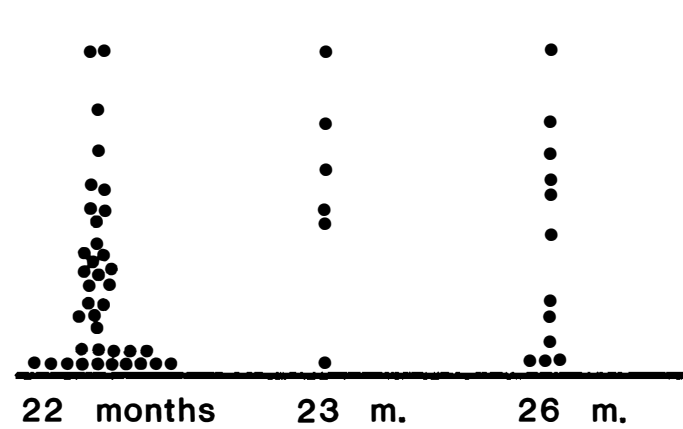

FIG. 2

Rate of urinary infection $\left({ }^{\circ}\right)$ in 60 patients under aseptic intermittent catheterization and in patients during follow-up period.

infection rate was expressed as the ratio of the frequency of infected urine (bacterial number $10,000 / \mathrm{ml}$ or more was defined as infection), to the number of urine cultures.

Study of the 60 patients during the aseptic intermittent catheterisation period ( 6 week duration), revealed a 12.6 per cent of urinary infection rate. Thirty-nine patients on self-catheterisation showed a I 4.7 per cent urinary infection rate during the 22 months follow-up period (Fig. 2). There was no statistical difference between aseptic intermittent catheterisation and selfcatheterisation $(\mathrm{p}<0.05)$, thus indicating that self-catheterisation as an outpatient and using the special kit, is as safe as aseptic intermittent catheterisation carried out during hospitalisation as far as urinary infection is concerned. Six female tetraplegics on assisted catheterisation had a 28 per cent urinary infection rate and is patients who could void without a catheter revealed a 33.2 per cent rate.

\section{Urinary complications}

Cystograms and intravenous pyelograms were reviewed every 6 months if there was any bladder deformity or deterioration of the upper urinary tract (Table I). In 39 cases of the self-catheterisation group 92 per cent showed no urinary complication, while 40 per cent of self-voiding cases showed changes in bladder outline.

\section{Discussion}

It has been generally believed that, if appropriate drainage of the bladder is not carried out during the phase of spinal shock, bladder recovery may be impaired in patients with spinal cord injury. 
Thus, aseptic intermittent catheterisation, preventing over-distension of the bladder, has been considered to be desirable treatment for the shocked bladder of patients with spinal cord injury (Guttmann and Frankel, I966).

The usefulness of the self-catheterisation method in the neuropathic bladder with complications has already been established (Lapides et al., I972). Comarr (I972) used a self-catheterisation method in patients with spinal cord injury in the acute recovery phase of the bladder and reported good clinical results. However, these authors used this as a temporary method until a balanced bladder could be achieved.

Several attempts have been made to overcome reflex contraction such as the administration of anti-cholinergic drugs (Ursillo, I967), caudal block (Shelden and Bors, I948), transection of the bladder (Essenhigh \& Yeates I973), multiple detrusor myotomy (Mahony \& Laferte I972) and prolonged bladder distension therapy (Dunn et al., I974; Whitfield and Mayo, I975; Ramsden et al., 1976; Pengelly et al., I978; Delaere et al., I980).

Delaere et al. carried out distension of the bladder under epidural anaesthesia in 53 cases with unstable bladders, eight of whom had spina bifida and spinal paralysis or both, but the results were discouraging because of recurrence of the bladder contraction and other complications. It is not clear why over-distension of the bladder is not effective once reflex contraction has occurred.

In view of this we believe that over-distension of the bladder in the period of shock should be accepted for paraplegic patients with complete cord lesion to eliminate subsequent urinary incontinence.

We initiate strict aseptic intermittent catheterisation in the first week after admission to prevent over-distension of the bladder until the precise diagnosis is established. Then patients with incomplete spinal cord injury and male tetraplegics are managed in the same regimen thereafter and many achieve good voiding with a balanced bladder function. Sixty patient with a complete lesion were considered suitable for over-distension therapy and this regimen had been continued until they could catheterise themselves. As a result 33 out of 52 UMN lesion patients had hypo-active bladder contraction and 33 out of 45 patients with intermittent (self or assisted), catheterisation were completely continent during their social activities. The urinary infection rate of the self-catheterisation group was similar to that of aseptic intermittent catheterisation.

These results of our clinical study demonstrated that over-distension therapy of the bladder in the early shock stage enables the patient to perform self-catheterisation in the later stage with a low risk of urinary infection, incontinence or complications.

\section{RÉSUMÉ}

On a entrepris la thérapie par surdistension avec 60 malades pendant la période de choc vertébral après la blessure complète de la moelle épinière. Quanante-cinq d'entre ceux-ci ont développé la fonction de vessie décompensée hypo-active du neurone moteur supérieure (UMN) et 39 en sont parvenus à une activité sociale satisfaisante sans incontinence urinaire à l'aide de l'autocathétérisme. L'autocathétérisme paraissait un moyen plus sûr et plus confortable de traitement urinaire que la méthode de vider par déclenchement chez les paraplégiques qui souffraient d'une blessure complète de la moelle e Ipinière. Il s'agit ici d'une communication préliminaire puisqu'on espère qu'une étude comparative suivra en temps utile. 


\section{ZUSAMMENFASSUNG}

Man hat die Überdistentionstherapie mit 60 Pazienten während der Rückengratschockperiode nach vollkommener Rückenmarkverletzung ausgeführt. Fünfundvierzig davon haben hypoaktive dekompensierte Blasenfunktion des oberen motorischen Neurons (UMN) entwickelt, und 39 haben befriedigende Sozialtätigkeit ohne Harninkontinenz mit Hilfe der Selbstkatheterisierung erzielt. Die Selbstkatheterisierung schien eine sicherere und bequemere Mittel von Harnbehandlung, als die Entleerung durch Auslösung, bei Paraplegischen mit voller Rückenmarkverletzung. Diese ist eine vorläufige Kommunikation, denn man hofft, dass ein Vergleichsstudium zur gegebenen Zeit folgen wird.

\section{REFERENCES}

ComarR, E. (1972). Intermittent Catheterization for the Traumatic Cord Bladder Patient. f. Urol., 108, 79-81.

Dunn, M., Smith, J. C. \& Ardran, G. H. (1974). Prolonged Bladder Distension as a Treatment of Urgency and Urge Incontinence of Urine. Brit. F. Urol., 46, 645652.

Delaere, K. P. J., Debruyne, F. M. J., Michiels, H. G. E. \& Moonen, W. A. (I980). Prolonged Bladder Distension in the Management of the Unstable Bladder. F. Urol., I24, 334-337.

Essenhigh, D. M. \& Yeates, W. K. (I973). Transection of the Bladder with Particular Reference to Enuresis. Brit. F. Urol., 45, 299-305.

GutTmann, L. \& Frankel, H. (I966). The Value of Intermittent Catheterization in the Early Management of Traumatic Paraplegia and Tetraplegia. Paraplegia, 4, 63-84.

Lapides, J., Diokno, A. C., Silber, S. J. \& Lowe, B. S. (i 972). Clean Intermittent SelfCatheterization in the Treatment of Urinary Tract Disease. F. Urol., 107, 458-46I.

Mahony, D. T. \& Laferte, R. O. (1972). Studies of Enuresis. IV. Multiple Detrusor Myotomy: a New Operation for the Rehabilitation of Severe Detrusor Hypertrophy and Hypercontractility. F. Urol., 107, 1064-1067.

Pengelly, A. W., Stephenson, T. P., Milroy, E. J. G., Whiteside, C. G. \& TurnerWarwick, R. (1978). Results of Prolonged Bladder Distension as Treatment for Detrusor Instability. Brit. F. Urol., 50, 243-245.

Ramsden, P. D., Smith, J. C., Dunn, M. \& ARdran, G. M. (1976). Distension Therapy for the Unstable Bladder: Later Results Including as Assessment of Repeat Distension. Brit. F. Urol., 48, 623-629.

Shelden, H. C. \& BorS, E. (1948). Subarachnoidal Alcohol Block in Paraplegia: Its Beneficial Effect on Mass Reflexes and Bladder Dysfunction. F. Neurosurg., 5, 385-39I.

Ursillo, R. C. (1967). Rationale for Drug Therapy in Bladder Dysfunction. pp. I 87-190 Neurogenic Bladder, ed. S. Boyarsky, Williams and Wilkins, Baltimore, I967.

Whitfield, H. N. \& Mayo, M. E. (I975). Prolonged Bladder Distension in the Treatment of the Unstable Bladder. Brit. F. Urol., 47, 635-639. 